\title{
Antibacterial gel dispenser with automated thermometer
}

\section{Dispensador de gel antibacterial con termómetro automatizado}

\author{
GONZALEZ-MONZON, Ana Lilia†*, TORRES-ARREOLA, León Guillermo, PIÑA-ALCANTARA, \\ Henry Cristopher and GODINEZ-TREJO, Roberto Carlos
}

Tecnológico Nacional de México, Tecnológico de Estudios Superiores de Jilotepec

ID $1^{\text {st }}$ Author: Ana Lilia, González-Monzón / DOI: 0000-0002-0280-0525, CVU CONACYT ID -151293

ID $1^{\text {st }}$ Co-author: León Guillermo, Torres-Arreola / DOI: 0000-0002-4848-2868, CVU CONACYT ID -154255

ID $2^{\text {nd }}$ Co-author: Henry Christopher, Piña-Alcántara / DOI: 0000-0001-5726-2915, CVU CONACYT ID: 719620

ID $3^{\text {rd }}$ Co-author: Roberto Carlos, Godínez-Trejo / DOI: 0000-0002-9592-1536

DOI: $10.35429 / J I D .2021 .13 .5 .16 .21$

Received July 23, 2021; Accepted October 30, 2021

\begin{abstract}
Abstrac
The SARS-CoV-2 virus. Declared a health emergency at the international level since its origin in Wuhan (China) in December 2019, the spread occurs by an infected person who exhales droplets of saliva and contagion occurs when we touch contaminated surfaces or people and touch our eyes, nostrils or mouth. Therefore, some prevention measures are used to avoid contagion, such as social distancing, the use of face masks or a mask and the use of antibacterial gel which is of great importance because it is used in all public places to prevent the risk. contagion. Therefore, the objective is to make an automatic antibacterial gel dispenser for the Tecnológico de Estudios Superiores de Jilotepec to minimize the risk of contagion. The device itself works by means of a sensor that when putting the hand detects and dispenses the gel, at the same time it takes the temperature that the reading shows on the screen, considering that it is one of the main symptoms of the disease, this contributes to have a preventive in the disinfection of the hands with gel and temperature measurement.
\end{abstract}

Automated, Dispenser, Prevention

\begin{abstract}
Resumen
El virus SARS-CoV-2. Declarado como emergencia sanitaria a nivel internacional desde su origen en Wuhan (China) en diciembre de 2019, la propagación se da por una persona infectada que exhala gotitas de saliva y el contagio se produce cuando tocamos superficies o personas contaminadas y nos tocamos los ojos, fosas nasales o boca. Por lo tanto, se utilizan algunas medidas de prevención para evitar el contagio, como el distanciamiento social, el uso de cubrebocas o mascarilla y la utilización de gel antibacterial el cual es de gran importancia porque se utiliza en todos los lugares públicos para prevenir el riesgo de contagio. Por lo tanto, el objetivo es realizar un dispensador de gel antibacterial automático para el Tecnológico de Estudios Superiores de Jilotepec para minimizar el riesgo de contagios. A si mismo el dispositivo funciona por medio de un sensor que al poner la mano detecta y dispensa el gel, al mismo tiempo toma la temperatura que se muestra la lectura la pantalla, considerando que es uno de los síntomas principales de la enfermedad, esto contribuye a tener una preventiva en la desinfección de las manos con gel y toma de temperatura.
\end{abstract}

Automatizado, Dispensador, Prevención

Citation: GONZALEZ-MONZON, Ana Lilia, TORRES-ARREOLA, León Guillermo, PIÑA-ALCANTARA, Henry Cristopher and GODINEZ-TREJO, Roberto Carlos. Antibacterial gel dispenser with automated thermometer. Journal Innovative Design. 2021, 5-13: 16-21

*Correspondence to the Author (e-mail: ana.gm@jilotepec.tecnm.mx)

$\dagger$ Researcher contributing as first author. 


\section{Introduction}

The prototype of an automatic gel dispenser, by means of an arduino microcontroller As a result of SARS-CoV- 2 has taken preventive measures to avoid contagion, it is necessary to take measures to take temperature since it is one of the symptoms of a person with Covid, as well as mouth covers and use of antibacterial gel on the hands, which is provided upon entering the institution by the surveillance personnel who, through a manual dispenser, distributes it and then takes the temperature one by one.

This causes a slow process and also puts at risk the people who do it, so if there is an automatic dispenser then the processes will be faster and safer, Also being automated avoids that people have contact with the gel dispenser and the thermometer provides the temperature reading on the screen that can be viewed personally.

In the first section of development we find the information of the components that make up the prototype such as the arduino, the pump, the control sensors, and the display. In section number two of design we find the design of the housing and the electronic plan. Section three is the methodology used for the development process of the prototype, which is the CDIO.

Section four shows the results of the gel dispenser prototype, and finally the conclusions.

\section{Development \\ Micro controller}

It is a programmable integrated circuit, capable of executing the orders recorded in its memory. A Microcontroller includes inside it the three main functional units of a computer: central processing unit, memory and input / output peripherals, the Arduino Nano board its ATM328P processing unit which is the same of an Arduino UNO, but without occupying the same space, being small and having input / output pins enough for the census and activation functions. See figure 1 .

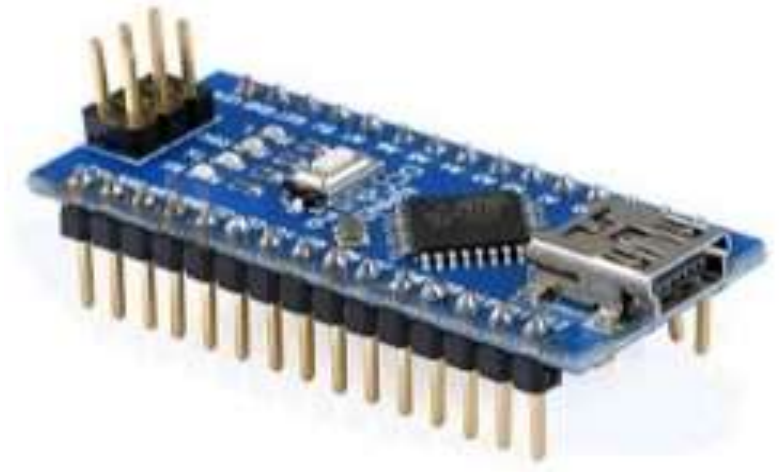

Figure 1 Arduino NANO (Arduino 2015)

\section{6x2 lcd screen}

LCD stands for Liquid Crystal Dysplay, a device used for displaying different types of content or information graphically, by using different characters, symbols or drawings. The second part of this term, 16x2, refers to the fact that the display has two rows, each with the capacity to display up to sixteen characters, symbols or figures, according to its programming. This display will show messages of prevention measures, as well as the user's body temperature. See figure 2 .

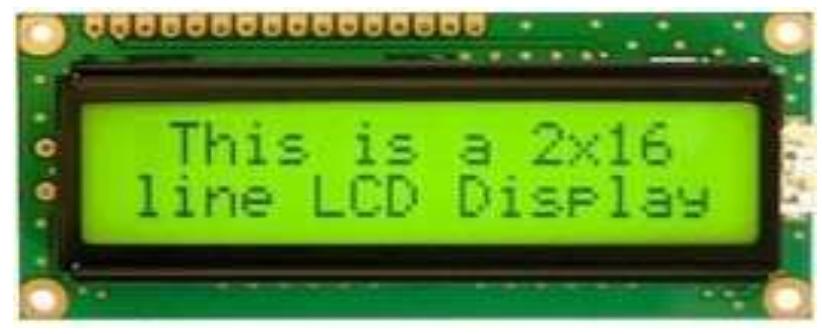

Figure 2 LCD display (prometec 2021)

\section{I2C Module}

The I2C module for LCD allows communication between an Arduino or microcontroller and a LCD16x2 via I2C, which facilitates connections when carrying out any type of application.

This adapter allows to manage in a much more optimal way the port distribution since the data presentation can be carried out through only two data cables and two power cables compared to using the LCD directly to the controller. See figure 3. 


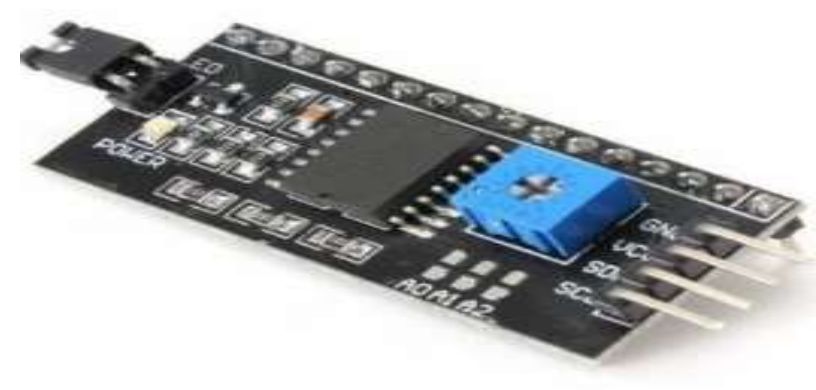

Figure 3 I2C module (Arduino 2015)

\section{Air pump}

Air pumps were used as they are strong enough to move the antibacterial gel by means of the vacuum pressure they generate, compared to a $5 \mathrm{v}$ submersible pump that the viscosity of the antibacterial gel could burn the motor. See Figure 4

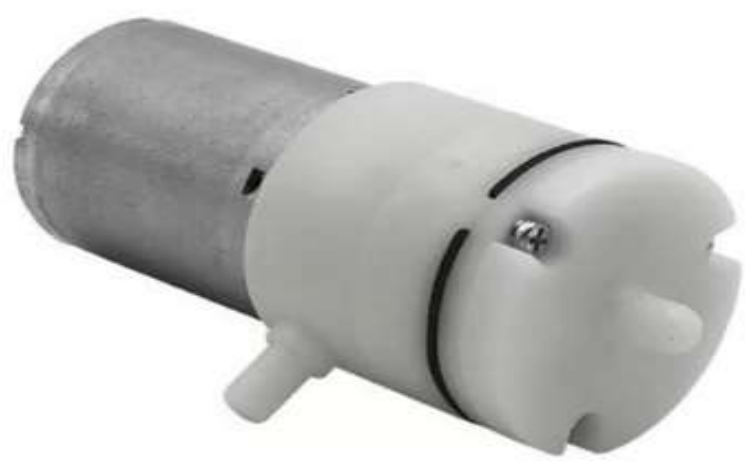

Figure 4 Air pump (2020 flames)

\section{Temperature sensor}

The MLX90614 Infrared Temperature Sensor is a silicon chip with a thin micro machined membrane, designed to be sensitive to infrared radiation emitted by an object at a distance having a wide working range for objects from $70^{\circ} \mathrm{C}$ to $380^{\circ} \mathrm{C}$, with an accuracy of $0.5^{\circ} \mathrm{C}$. as well as the LCD display The sensor output is an I2C type digital communication interface. See figure 5

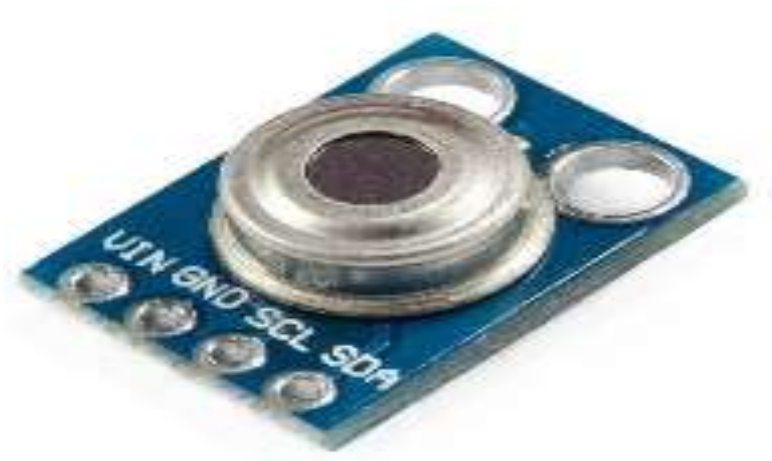

Figure 5 Temperature sensor (solerpalau 2021)

\section{Triac BT 137}

Triac is a three-terminal semiconductor device $(\mathrm{T} 1, \mathrm{~T} 2, \mathrm{G})$ which is used to control the current flow, The triac can be triggered independently of gate bias $(\mathrm{G})$, i.e. by positive or negative gate current. Which will be controlled by Arduino to make the activation of the air pump and supply the gel. See figure 6

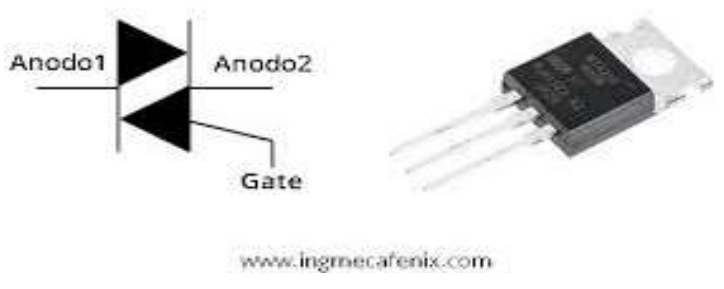

Figure 6 Triac bt 137

\section{DESIGN}

The circuit for the operation of the gel dispenser that was made with software to test and connect the data output pins A5 and A4 the Arduino to detect the user by sending a digital output to the pins of the led' showing green as of the pump to initial pumping antibacterial gel showing on the a sign where it indicated access to the The $\mathrm{I} 2 \mathrm{c}$ module is connected to an I2c module to avoid the excess of wires so in the module are connected ground voltage and data input that are connected directly to pins 6 and 7 of the Arduino, then when the pumping is finished a signal is sent to the red led pin to indicate that the antibacterial gel should be applied. See image 6.

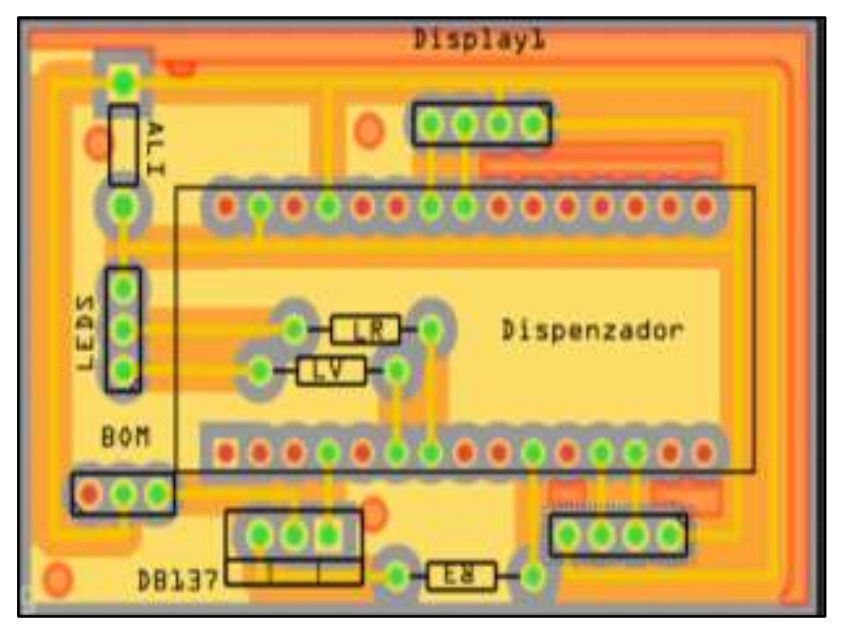

Figure 7 Electrical circuit Source: Own Elaboration 
The design of the automatic gel dispenser was carried out with the help of the software of Salid Works with which it is intended that the dispenser is manufactured in five pieces from poly-lactic acid (PLA). The first structure will contain the electronic components, as well as the hose outlet where the antibacterial gel is supplied.

This structure will measure $10 \mathrm{~cm} \times 7$ $\mathrm{cm}$ at the base, with a height of $5 \mathrm{~cm}$. For the assembly of the LCD screen with a measure of $7 \mathrm{~cm}$ wide $\times 2 \mathrm{~cm}$ high, on the left side it has two perforations where the LEDs will be assembled, one green to indicate when the user should apply gel or if it has already been applied with a measure of $.5 \mathrm{~cm}$ in diameter.

On the left side there is a hole where an on/off button will be located, as well as a rectangular hole where the power cable will pass, on the back side there is a rib with which it can be assembled to the gel container and can be fastened with screws. (See figure 8).

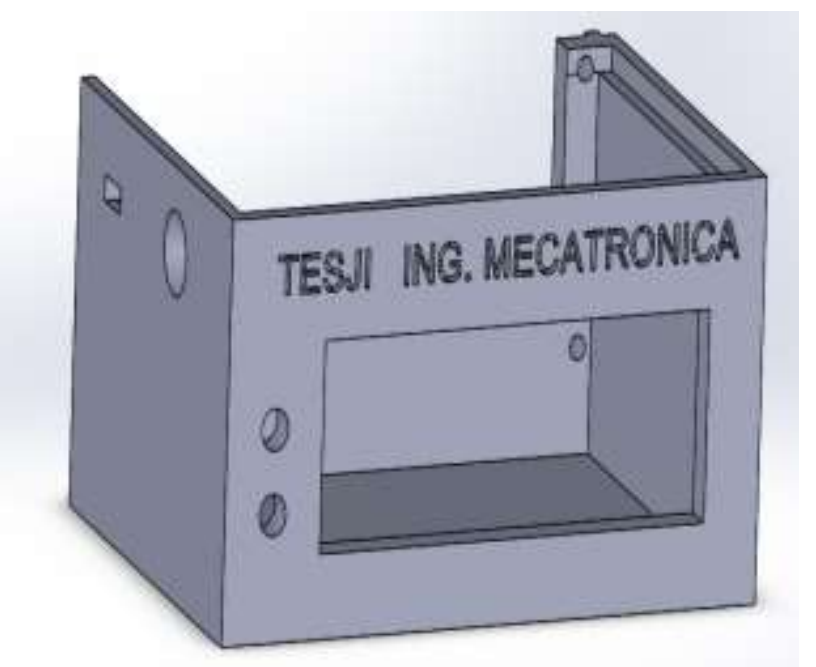

Figure 8 Front part

Source: Own Elaboration

The antibacterial gel tank is rectangular in shape with a space to locate the air pump so that it is not in contact with the liquid and produce an accident with the electrical components, the tank is designed for $500 \mathrm{ml}$ of antibacterial gel, For the assembly small holes were considered to hold the part where the electronic components will be placed, these pieces will be coupled by means of a rib on the back side of the first piece, in the upper part there is a space for the supply cover that will be placed by means of screws to 3 bars located in the corners to provide a better support. (See figure 9).

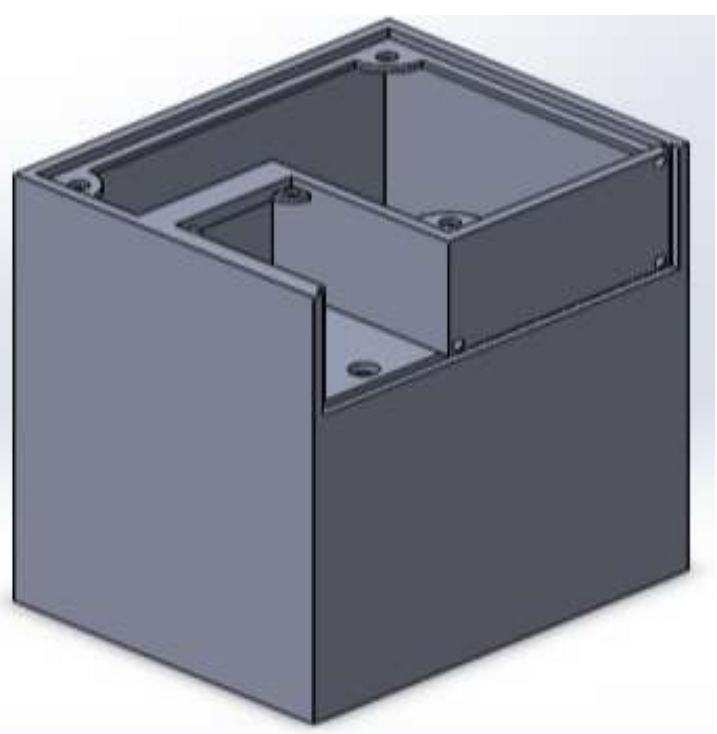

Figure $9 \mathrm{Gel}$ container

Source: Own Elaboration

The lids were designed for each one of the structures according to the measures and function of each piece. The first one is for the antibacterial gel container with an orifice designed for the recharge of the antibacterial gel or alcohol. (See figure 10).

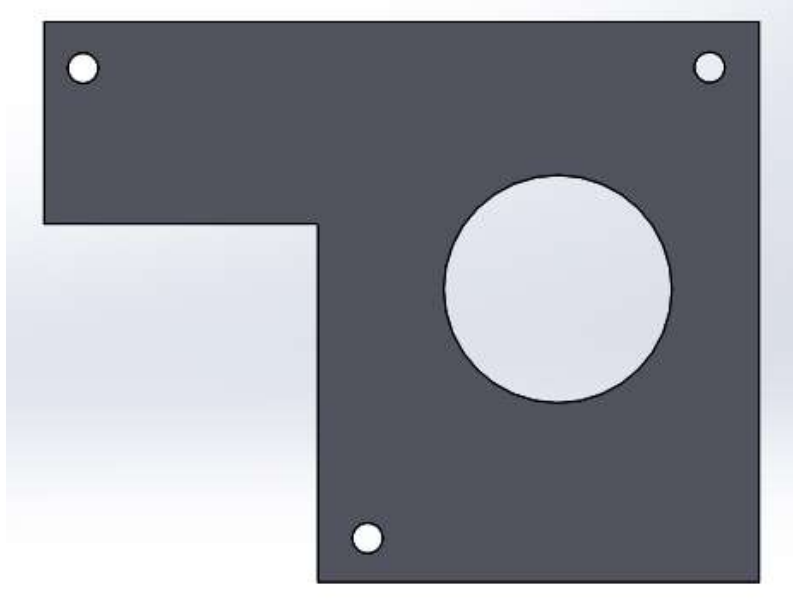

Figure 4 Container lid

Source: Own Elaboration

The second cover for the electronic components will join the pieces by means of four holes, two in each of the previous pieces. (See figure 11). 


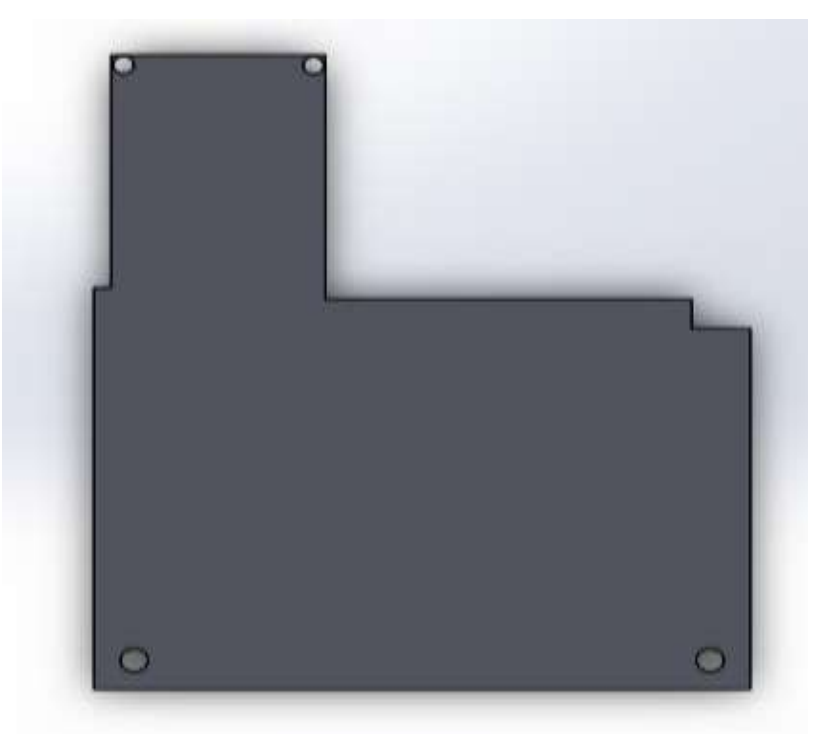

Figure 11 Front cover

Source: Own Elaboration

Having the 3D components already assembled with the structure, the device looks as follows. (See figure 12).

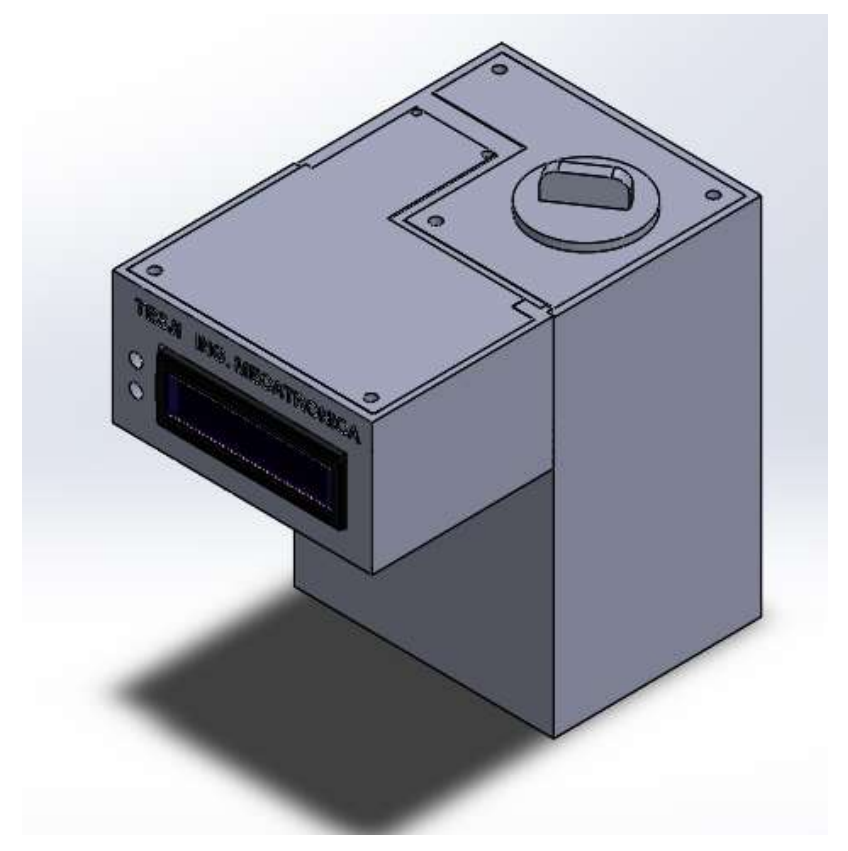

Figure 12 Antibacterial dispenser

Source: Own Elaboration

\section{Methodology to be developed}

The methodology implemented in the antibacterial gel dispenser is the Conceive Design - Implement - Operate (CDIO). It is an intervention methodology used mainly with engineering students that allows to face in an innovative and flexible way the problems worked on, emphasizing the engineering fundamentals established in the context.

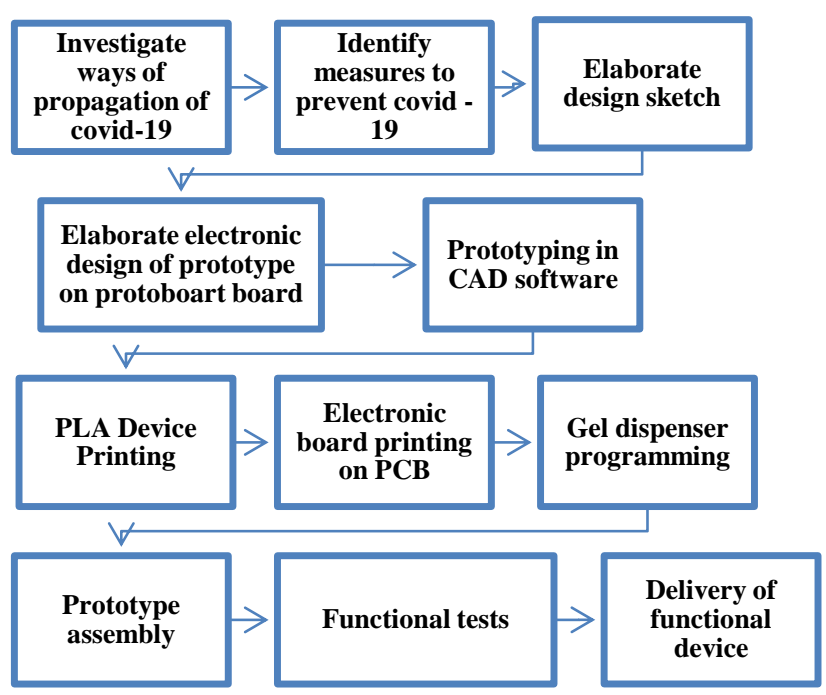

Figure 13 Methodology

Source: Own Elaboration

\section{Results}

The prototype that was made fulfills a functionality of sanitization of the user's hands without direct contact with the device allowing to have control with the access to the institution each time the antibacterial gel is provided, since it allows to dispense continuously and at the same time to take the temperature continuously avoiding that any person has contact with the gel container to provide it individually.

With the thermometer as it will automatically show the temperature on the screen at a low cost compared to similar products that exist in the market. This will reduce the waiting time for students and staff when taking the gel and their temperature by having quicker access. On the cost side, it is considered an economical prototype since its total cost is $\$ 2000$ considering all the mentioned components and its elaboration. See Figure 14. 


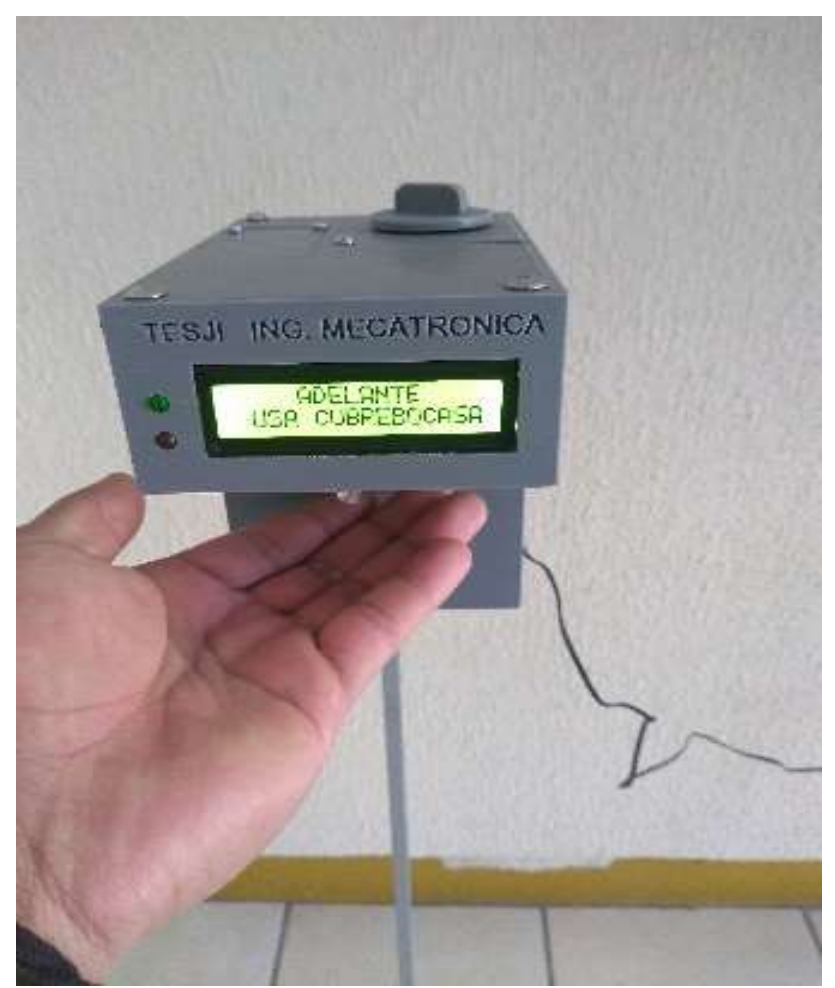

Figure 7 Dispenser

Source: Own Elaboration

\section{Conclusions}

Having a device with this type of functions at the entrances of each institution could be of great help in preventing contagion and avoiding contact with surfaces that may be contaminated with the virus or bacterial diseases, without the need to occupy personnel who are in charge of the application of the gel, putting at risk of contagion and spread of the virus. Keeping in mind the prevention measures for covid19 that will help to end the spread of this pandemic.

The development of this project required knowledge about computer aided drawing (CAD), as well as c++ programming language to control the Arduino microcontroller, knowledge about electronics to develop the PCB board.

\section{Acknowledgment}

We would like to thank the Tecnológico de Estudios Superiores de Jilotepec for the support provided for the publication of this article.

\section{References}

Bragado, D. (25 de MAYO de 2009). blogspot.mx. Obtenido de blogspot.mx: http://electroimn.blogspot.mx/
Didácticos, R. (15 de Diciembre de 2018). Robótica, Automatización, control industrial, microcontroladores, electrónica digital. Obtenido de Comparación Arduino Uno Arduino Nano: http://robotsargentina.com.ar/didactica/comparacionarduino-uno-arduinonano/\#: :text=El\%20convertidor\%20de\%20US B\%20a,controlador\%20FTDI232\%20USB $\% 20$ a\%20serie.

Gonzalez, R. Z. (15 de Octubre de 2014). Universidad Autonoma de Mexico. Obtenido de "Dispensador automatico de croquetas": http://www.ptolomeo.unam.mx:8080/xmlui/bits tream/handle/132.248.52.100/5764/Tesis.pdf?se quence $=1$

kevin, N. (21 de Noviembre de 2011). blogspot.mx. Obtenido de blogspot.mx: http://electrokadpdcetis.blogspot.mx/2011/11/q ue-es-un-electroiman-e-historia.html

Llamas, L. (16 de junio de 2016). Detector de obstaculos son sensor infrarrojo y arduino. Obtenido de Ingenieria Informatica y diseño: https://www.luisllamas.es/detectar-obstaculoscon-sensor-infrarrojo-y-arduino/

OMS, O. (11 de Marzo de 2020). Brote de enfermedad por coronavirus (COVID-19). Obtenido de Nuevo Coronavirus 2019: https://www.who.int/es/emergencies/diseases/n ovel-coronavirus-2019/advice-for-public/q-acoronaviruses

Pérez, J. L. (25 de Marzo de 2018). Proyecto sensor de movimiento. Obtenido de instituto Tecnologico del Parral: https://www.academia.edu/22115982/Proyecto_ sensor_de_movimiento

Salas, M. A. (2019). Electronica Digital. Mexico, Guadalajara, Mexico: Trillas. 